\title{
Minor Immunoreactivity in GDNF-, BDNF-, or NT-3-Treated Substantia Nigra Allografts
}

\author{
Masaki Shinoda, ${ }^{1,3}$ Barry J. Hoffer, ${ }^{2}$ and Lars Olson \\ ${ }^{\prime}$ Department of Neuroscience, Karolinska Institute, Stockholm, Sweden; \\ ${ }^{2}$ Department of Pharmacology, University of Health \& Science Colorado, Denver, CO, USA; \\ ${ }^{3}$ Department of Neurosurgery, Tokai University, Kanagawa, Japan
}

\section{SUMMARY}

Glial-cell-line-derived neurotrophic factor (GDNF) stimulates the survival of dopaminergic neurons. Little is known, however, about the possible immune sequelae of GDNF exposure or of exposure to other putative trophic factors. To address these questions, pieces of mesencephalic tissue, substantia nigra, from 15-day-old donor embryos were transplanted into the anterior chamber of the eye of adult male SpragueDawley recipient rats. At 5-day intervals, an aliquot $(0.5 \mu \mathrm{g})$ of GDNF, brain-derived neurotrophic factor (BDNF), neurotrophin-3 (NT-3), or cytochrome-C (CC) was injected into the anterior chamber of the eye of the recipients, and the sizes of the transplants were measured. GDNF increased transplant survival and growth. On day 42, all rats were sacrificed, and the grafts were evaluated by cresyl-violet staining and by immunohistochemistry using antibodies raised against neurofilament (NF), tyrosine hydroxylase, or glial fibrillary acidic protein (GFAP), as well as the following monoclonal antibodies: OX-38 anti-CD4, OX-8 anti-CD8, OX-18 anti-MHC class I, OX-6 antiMHC class II, OX-42 anti-CD11b, R-73 anti- $\alpha$ and anti- $\beta$ T-cell receptor, and ED1 raised against monocytes/macrophages. BDNF-treated grafts showed only weak immunoreactivity, and even weaker reactions were seen in grafts treated with NT-3, GDNF, or CC. No single immune system marker was significantly elevated in grafts from any treatment group. We used OX-42 and ED1 to study possible alterations of microglial components. Ramified microglial cells were found in GDNF-treated grafts and to a lesser extent in NT-3 and BDNFtreated grafts. ED1-labeled reactive microglial components were found in NT-3- and BDNFtreated grafts. Additionally, large and rounded OX-42-positive phagocytic cells were found in NT-3-treated grafts. Together with our previous finding that GDNF treatment of spinal cord transplants activates immune responses and leads to microglial activation, our data demonstrate that although treatment with GDNF and to some degree with BDNF can enhance immune responses to immunogenic grafts, such as fetal spinal cord grafts, but the trophic factors per se do not elicit any marked response in non-immunogenic grafts like substantia nigra.

\section{KEY WORDS}

transplantation immunology, glial-derived neurotrophic factor, brain-derived neurotrophic factor, neurotrophin-3, TGF- $\beta$, microglia,

\section{INTRODUCTION}

Reprint address:

Dr. Masaki Shinoda

Department of Neurosurgery

Tokai University School of Medicine

Bohsei-dai, Isehara, Kanagawa, Japan 259-11

Tel: +811463931121; Fax: +811463911295
Glial-cell-line-derived neurotrophic factor (GDNF) shows trophic effects not only on ventral mesencephalic dopaminergic neurons $14,6,11,18$, $37,44,48 /$ but also on spinal cord motoneurons 
$/ 30,54 /$, but little is known about the possible immune sequelae of host and graft exposure to GDNF or to other putative trophic factors. In allogeneic but not syngeneic intraocular fetal spinal cord transplants, GDNF upregulates the expression of major histocompatibility (MHC) loci antigens and activates graft-derived microglial cells /40/. GDNF mRNA in the cortex and hippocampus is upregulated in such pathological conditions as experimentally induced status epilepticus in the hippocampus and striatum $/ 38 /$.

GDNF is a member of the transforming growth factor- $\beta$ (TGF- $\beta$ ) superfamily $/ 24 /$ of proteins that are produced and secreted by a variety of immunocytes $/ 52 /$. The TGF- $\beta$ proteins are wellknown immunomodulators having the following immune functions: (a) inhibit the proliferation of thymocytes, T-cells, B-cells, and natural killer (NK) cells; (b) inhibit the generation of cytotoxic macrophages; (d) inhibit IgG and IgM production; (e) switch B-cells from IgG to IgA production; (f) modulate the production of cytokines; and (g) serve as chemoattractants for monocytes and neutrophils $152 /$. TGF- $\beta$ proteins, however, have also been reported to elicit strong immune responses (reviewed in $/ 10,15,28,50 /$ ).

Intraocular transplantation of central nervous system (CNS) tissue provides a unique method for examining the in vivo effects of trophic factors. Such proteins can be selectively administered into the anterior chamber, thus minimizing remote or indirect drug effects $/ 6,18,44,49 /$. For example, fetal substantia nigra tissue grafted to the anterior chamber of the eye responds to GDNF /44/. Of particular relevance for immunological studies is that allogeneic grafts, even when manifesting good survival and growth, contain significant amounts of immunoreactive elements. In addition, area-specific differential immune responses are elicited after grafting $/ 39 /$.

In the study presented here, we used embryonic substantia nigra transplants and an in oculo graft model as appropriate targets for GDNF activity to determine whether the TGF- $\beta$ superfamily trophic molecule, in addition its stimulatory effects, might induce or interact with immune elements. To monitor the various elements of the immune system after GDNF administration, we used monoclonal antibodies (mAbs) raised against the following
T-cell, B-cell, or monocytelmacrophage cell-surface antigens: rat $\mathrm{CD} 4(\mathrm{OX}-38)$, rat $\mathrm{CD} 8$ (OX-8), rat MHC class I (OX-18); rat MHC class II (OX-6). MAb (OX-42) raised against rat $\mathrm{CD} 11 \mathrm{~b}$ identifies cellular complement-receptor type 3 (CR3), which is found on the surface of classical (ramified) and ameboid and/or reactive microglial subtypes /14,36,/45/. MAb ED-1, raised against rat monocytes and macrophages, is a cytoplasmic marker of macrophages or activated microglia or both $/ 8 /$ that localizes only to cells of the monocytic lineage $19,45 /$. We used allogeneic grafts to vary the basal immune status of the CNS tissue. For purposes of comparison, we tested other trophic factors from the neurotrophin family, including brain-derived neurotrophic factor (BDNF), which has survivalpromoting activity on substantia nigra $/ 17,21 /$, and neurotrophin-3 (NT-3), which influences immune reactions in grafted CNS tissue /40/.

\section{MATERIALS AND METHODS}

\section{Intraocular grafting procedures}

Young adult male Sprague-Dawley rats (SD rats, B \& K, Sweden) weighing $150 \mathrm{~g}$ each were used as recipients of intraocular grafts. Fetuses from pregnant female rats were used as donors of embryonic mesencephalic tissue grafts. On the 15th embryonic-day (E15), pieces (1-3 mm wide) of substantia nigra were dissected out from the fetuses and bilaterally grafted, under ether anesthesia, to the anterior eye chamber of the eye of the adult hosts. To prevent prolapse of the iris, the eyes were pretreated with a drop of $1 \%$ atropine solution. The grafts were placed on the anterior surface of the iris through a small opening in the cornea as previously described $/ 29 /$. Every 5th day after grafting (up to day 40), the volume of each transplant was estimated by stereomicroscopic observation, measuring the longest diameter multiplied by the diameter perpendicular to it. Every 5th day, each eye was injected with $5 \mu \mathrm{L}$ of a solution containing $0.5 \mu \mathrm{g}$ of one of the following factors: (a) GDNF (100 $\mu \mathrm{g} / \mathrm{mL})$, (b) cytochrome C (CC, $100 \mu \mathrm{g} / \mathrm{mL})$, (c) BDNF $(100 \mu \mathrm{g} / \mathrm{mL})$, (d) NT-3 $(100 \mu \mathrm{g} / \mathrm{mL})$ 149/. Donor material from any one dam was equally distributed among all treatment groups. The 
measured sizes of the grafts correlate well with the actual weight of the grafts at sacrifice $/ 5 /$.

\section{Immunohistochemistry}

Forty-two days after transplantation, the host animals were deeply anesthetized with sodium pentobarbital $(60 \mathrm{mg} / \mathrm{kg}$, i.p.) and perfused via the ascending aorta with $50 \mathrm{~mL}$ of calcium-free tyrode solution $\left(37^{\circ} \mathrm{C}\right)$ and then with $300 \mathrm{~mL}$ of ice-cold fixative (4\% paraformaldehyde in phosphate buffer). Transplants attached to host irises were post-fixed by immersion for 30-60 $\mathrm{min}$ in the same fixative, rinsed in $10 \%$ sucrose, frozen, and then sectioned on a cryostat at $14 \mu \mathrm{m}$. Sections at periodicities of 8 to 12 were processed for glial fibrillary acid protein $\left(\right.$ GFAP, Sigma $\left.{ }^{\circledR}\right)(1: 100)$, neurofilament (NF, a kind gift from Prof. Doris Dahl( (1:400), and tyrosine hydroxylase (TH, Pel Freeze ${ }^{\mathbb{Q}}$ ) immunohistochemistry (1:00), or stained for cresyl violet. MAbs raised against rat CD4-clone OX-38, rat CD8-clone $\mathrm{OX}-8$, rat $\mathrm{CD} 11 \mathrm{~b}$-clone $\mathrm{OX}-42$, rat MHC class I-clone $\mathrm{OX}-18$, and rat ED-1 raised against monocytes and macrophages were purchased from Serotec ${ }^{\circledR}$; rat MHC class II-clone OX-6 was obtained from Pharmingen ${ }^{\circledR}$. Primary MAbs were diluted 1:1000, except for OX-42 (1:200) and ED-1 (1:300). All tissues were stored for $48 \mathrm{hr}$ at $4{ }^{\circ} \mathrm{C}$ in a humidified chamber. For OX-38, $0 \mathrm{X}-8,0 \mathrm{X}-42$, and $\mathrm{OX}-18$, the secondary antibody was Fluorescein-linked rabbit anti-mouse IgG. For GFAP, NF, and TH, Fluoresceinisothiocyante (FITC)-labeled goat anti-rabbit IgG served as the second antibody $/ 39,41 /$. For each graft, a "total immunological score" was calculated by a summation of the scores for CD4, CD8, MHC classes I and II. Immunological scores were based on cell counts as follows: scores of $0,0.5,1,1.5,2$, $2.5,3,3.5,4,4.5$, or 5 were given to grafts where the respective average numbers of immunoreactive cells/field of view, using a primary magnification of $20 \times$ were $0-2,3-7,8-12,13-17,18-22,23-27$, $28-32,33-37,38-42,43-47$, and $>48$. When in addition to cells, immunoreactive glial or fibrous processes or both were also noted, the scores were incremented by $0.5,1$, or 2 for small, moderate, or large amounts of MHC-I or MHC-II-positive material. Scores of OX-42 (CD1 1b) and ED-1 were $0,0.5,1,1.5,2,2.5,3,3.5,4,4.5$, or 5 given to grafts where these elements were found in $0-4,5-$ $14,15-24,25-34,35-44,45-54,55-64,65-74$, $75-84,85-94$, or $>95 \%$ of the area of the graft 140/. In addition, the TH-positive volume was estimated by scoring the percentage of the THpositive area at three different levels of the transplant and then calculating the averages. We used the Mann-Whitney $U$ test to determine the differences between paired groups.

\section{RESULTS}

\section{Effect of growth factors on graft growth}

Figure 1a shows the growth of intraocular substantia nigra grafts treated with different neurotrophic factors. GDNF treatment led to significantly larger graft volumes than $\mathrm{CC}(\mathrm{p}<0.05)$. Figure $1 \mathrm{~b}$ shows the volume of $\mathrm{TH}$-positive regions. GDNF-treated grafts had a significantly larger THpositive volume compared with NT-3 and CC $(p<0.05)$. Neither BDNF nor NT-3 had a significant effect on either graft growth or volume of THpositive areas in the grafts.

\section{Overall immune response to growth factors}

Figures 2-4 summarize the total immunological score and scores for each immune element. Although BDNF-treated allografts contained somewhat larger mean numbers of immune-related cells, including lymphocytes and antigen-presenting cells (Figs. 5,8b), the differences were not significant when compared with the control group (Figs. 2-4). Occasionally, NT-3 and BDNF treatments led to higher amounts of immune-related elements (Figs. 6,8c). GDNF treatment did not appear to cause any significant immune reactivity. All transplants contained very low numbers of OX38-positive elements (data not shown).

\section{Immunologic patterns for individual growth factors}

GDNF-treated transplants showed excellent neuronal survival (Figs. 7,8). MHC Class I-positive, ramified microglial cells could be identified, but only a few such cells were seen in the grafts. In addition, GDNF-treated grafts showed well-developed 


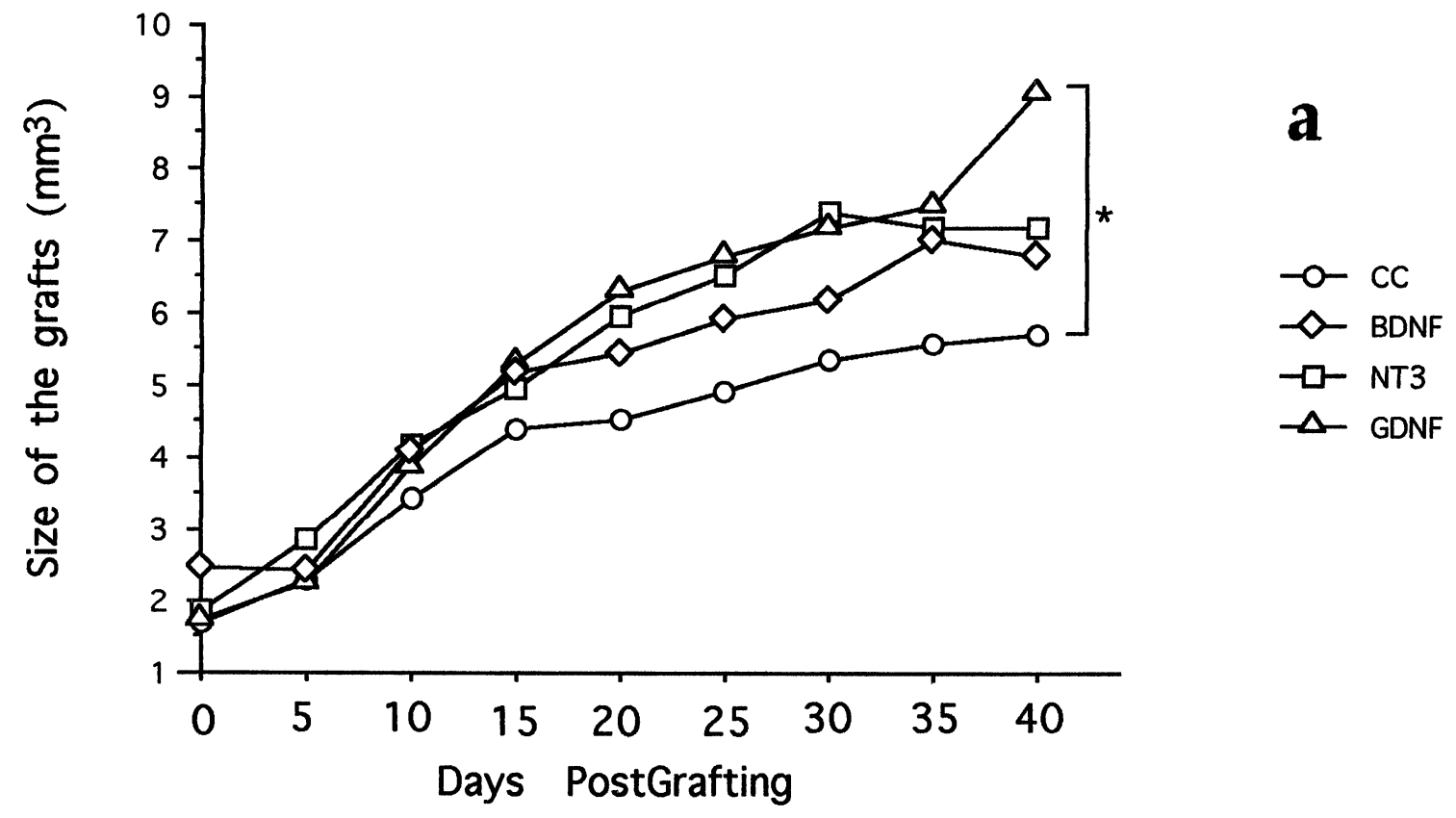

Fig. 1. a: Growth curves of intraocular transplants given GDNF (triangle) or BDNF (diamond), NT-3 (- $\square-$ ), and cytochrome-C (-O-) I Sprague-Dawley rats. GDNF-treated transplants showed increased growth (mean \pm s.e.m., ${ }^{*}=p<0.05$ ) compared with control, cytochrome-C treatment.

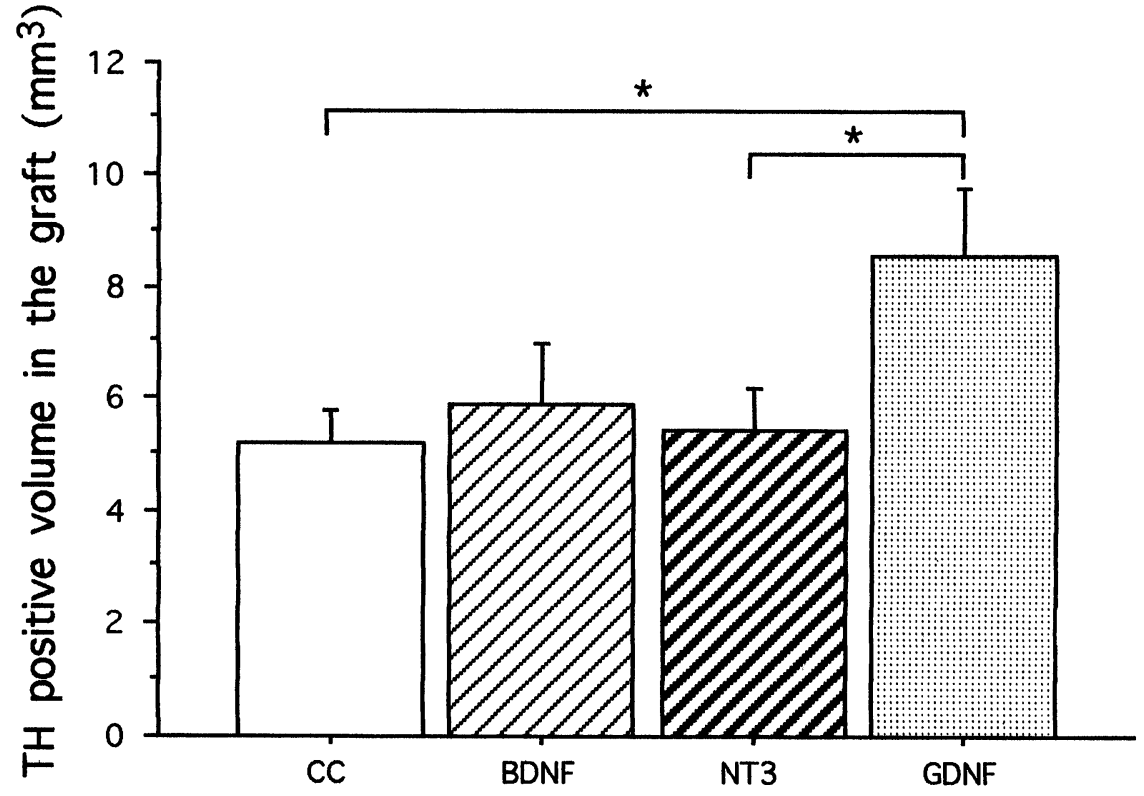

b

Fig. 1. b: TH-positive volume in grafts. GDNF treatment led to significantly larger TH-IR areas than BDNF, NT-3, or cytochrome-C treatment (mean \pm s.e.m., ${ }^{*}=p<0.05$ ). 


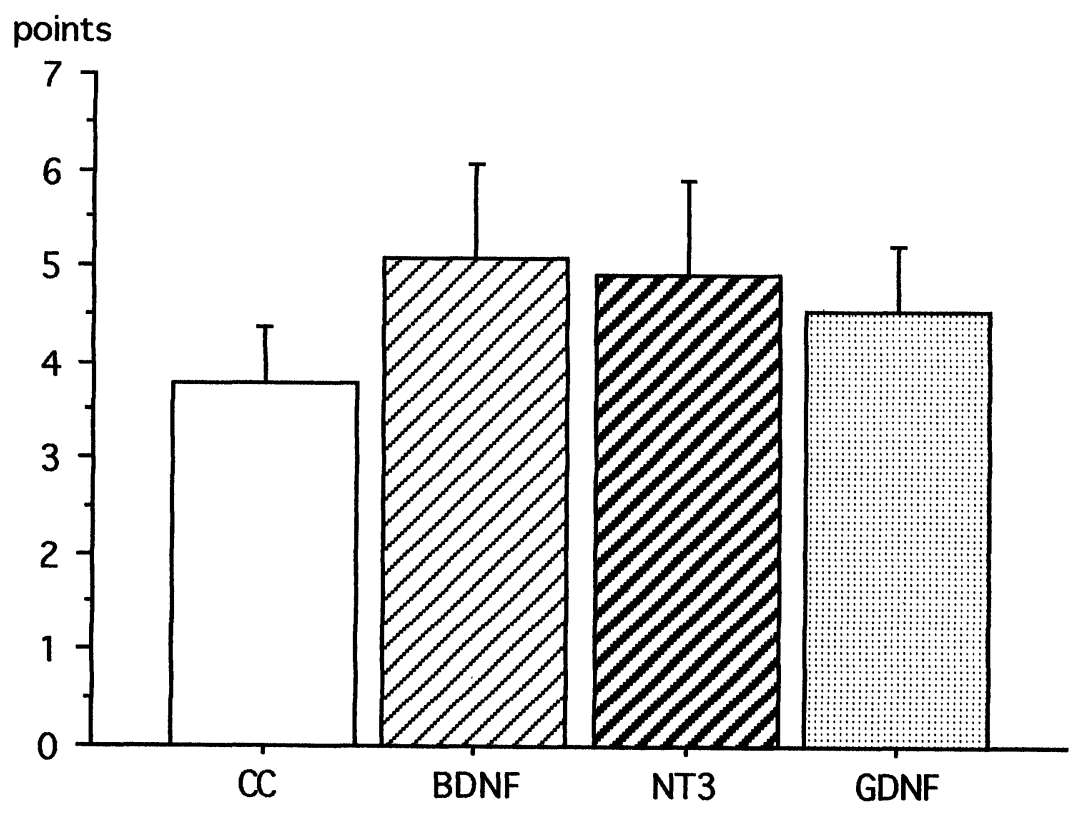

Fig. 2. Total immunological scores. BDNF, NT-3, and GDNF treatments causes only minor changes in mean scores. Differences were not significant.
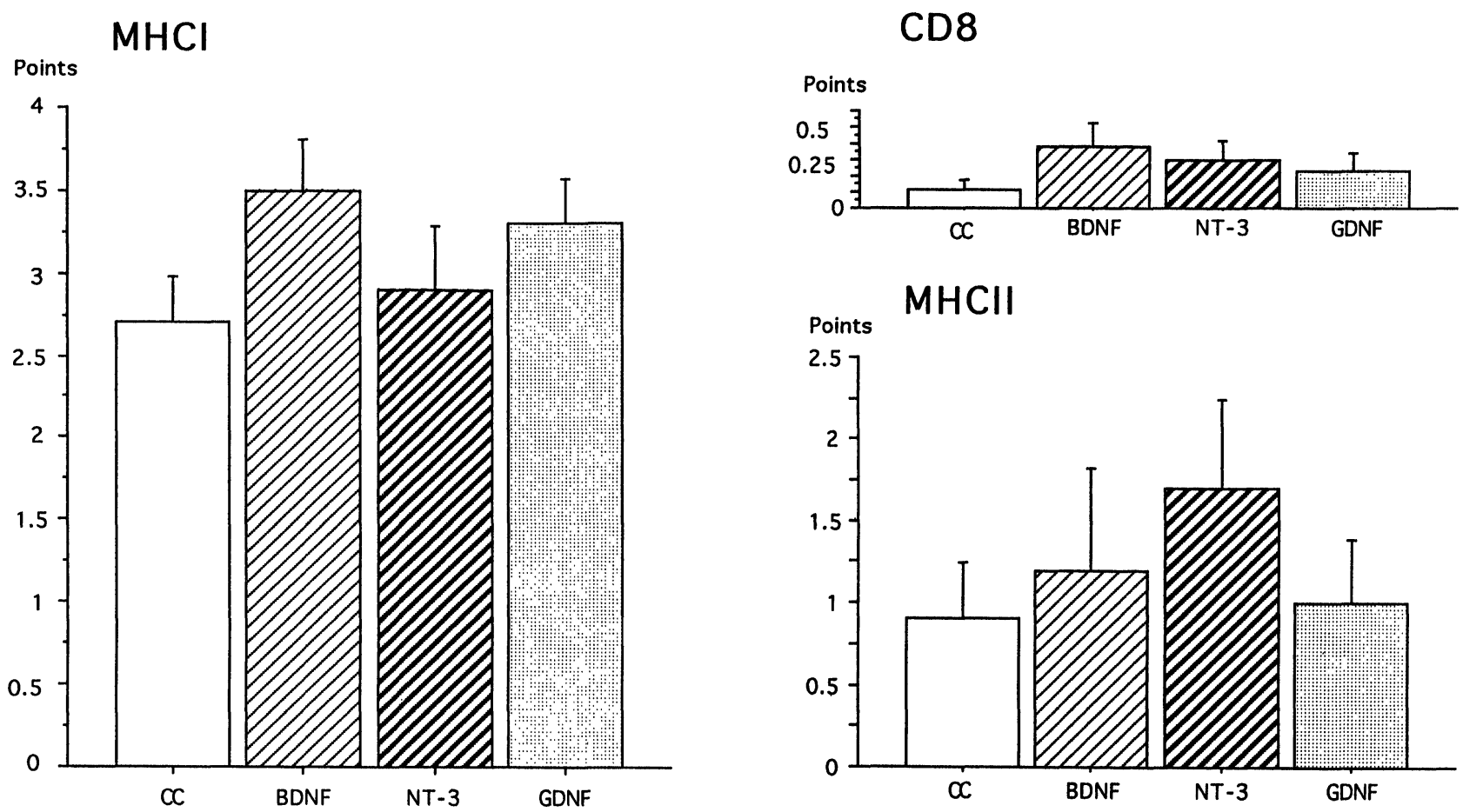

Fig. 3. Scores for individual immune markers. Scores of CD4 were excluded because they were close to zero. The NT-3 treatment group had a higher mean MHC class II expression score, but the difference was not significant. 
OX42-positive large, round microglial distribution
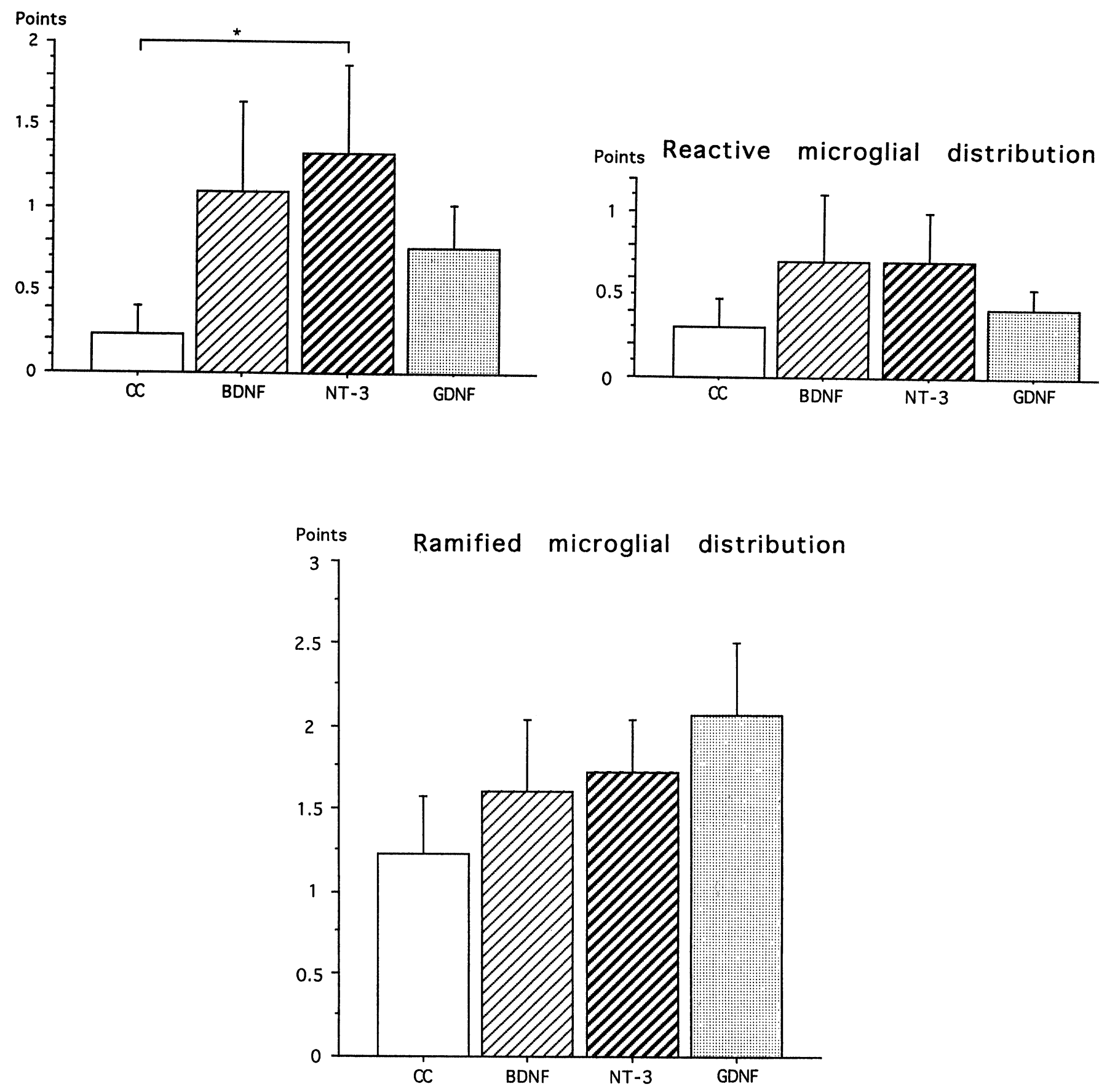

Fig. 4. Microglial alterations. GDNF-treated grafts had well-developed ramified microglial cells and fewer reactive microglial cells. NT-3-treated grafts had significantly higher numbers of OX-42-positive large and round microglial cells than the cytochrome-C-treated grafts $(\mathrm{p}<0.05)$. 

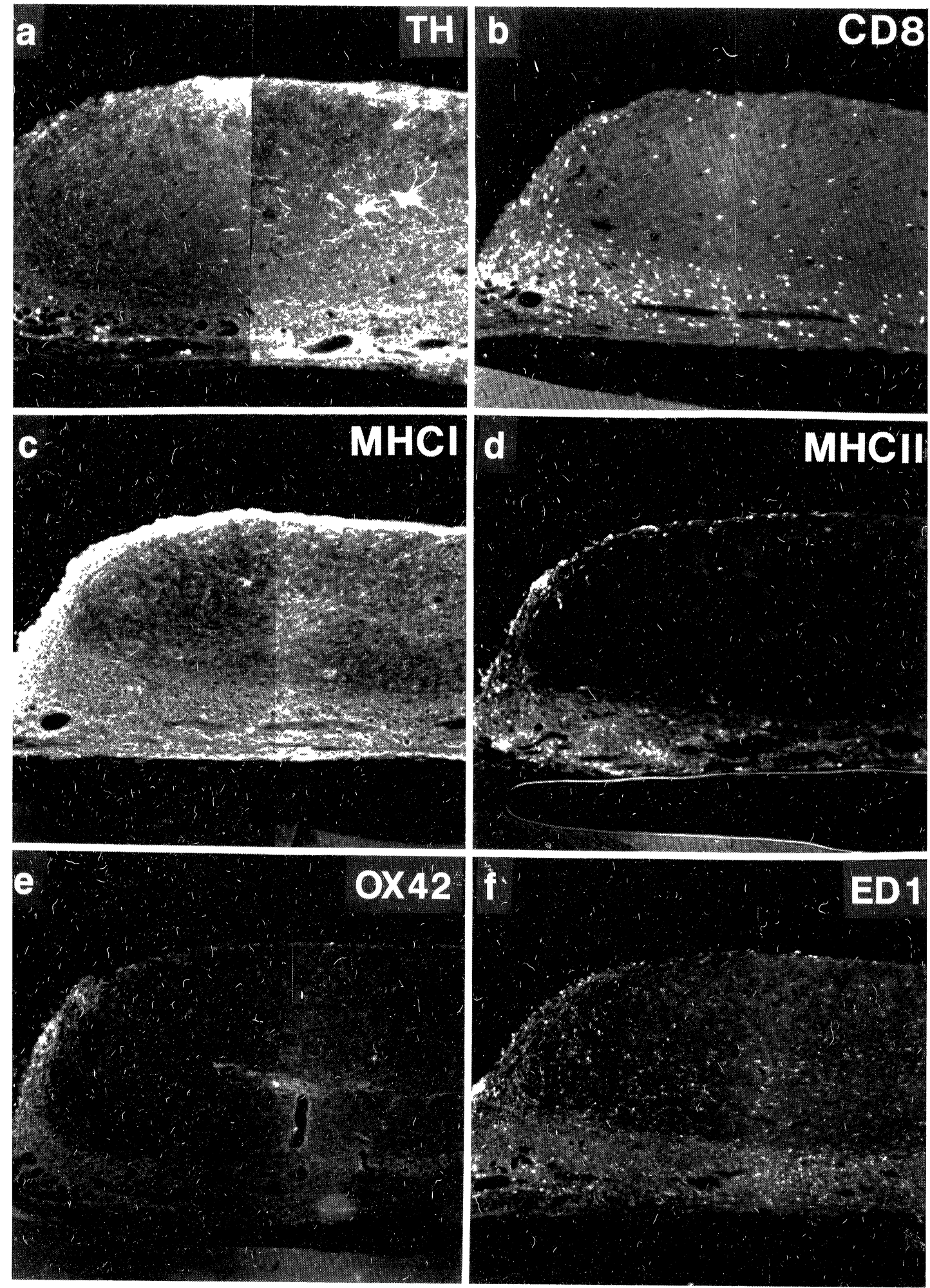

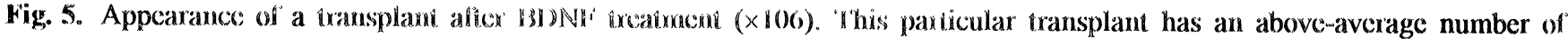

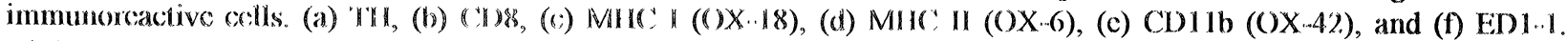
Higher numbers of immunocyles can bo scein with (OX-83 antibodics, and OX-42-positive large and round microglial cells

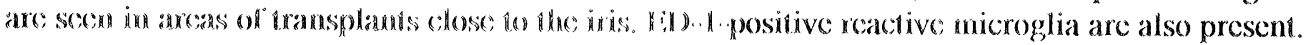



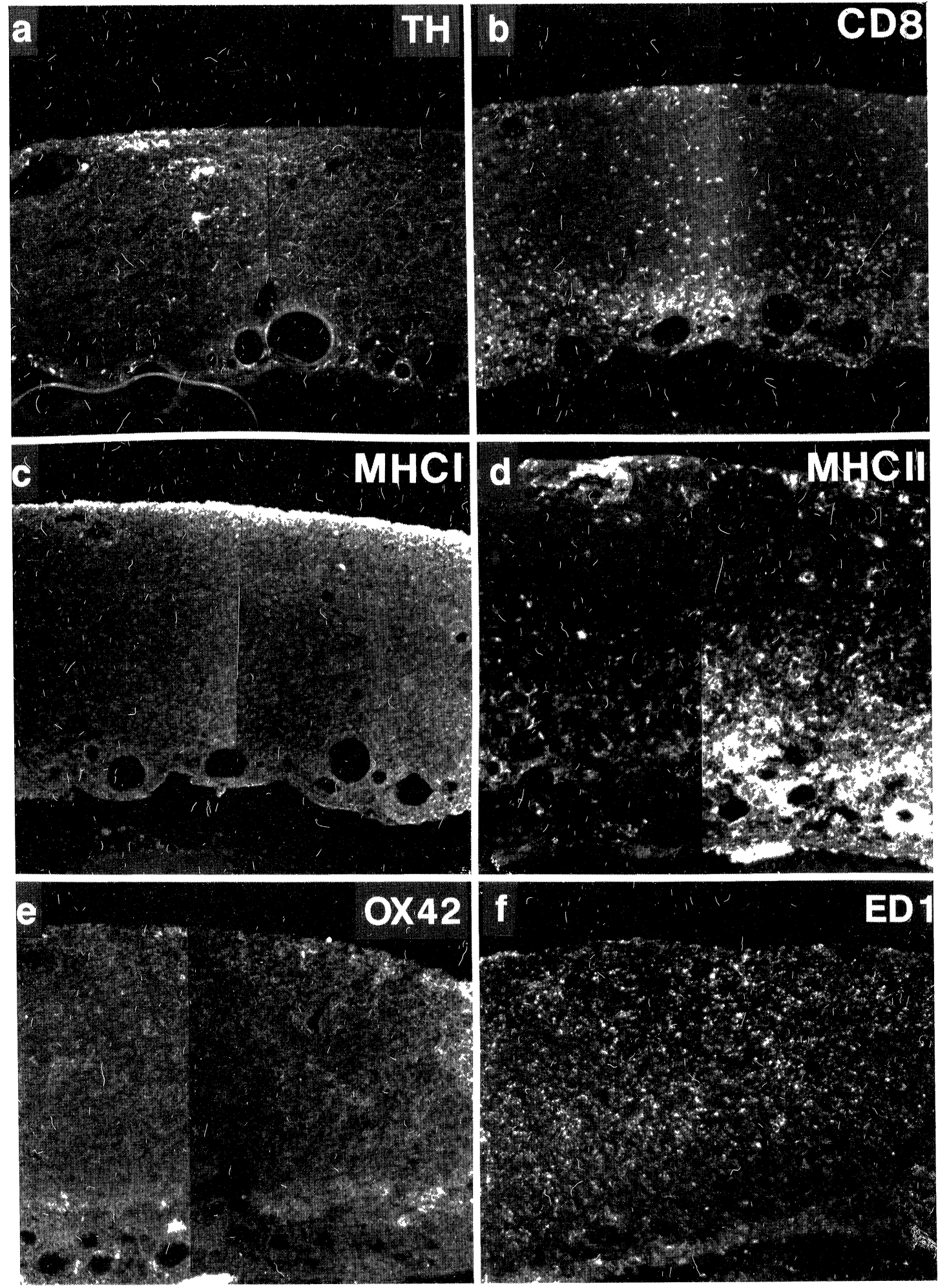

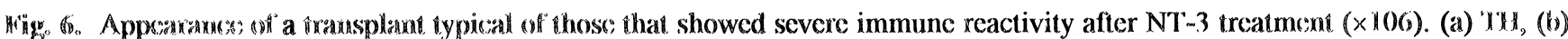

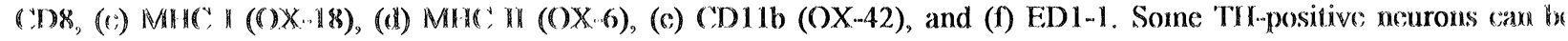

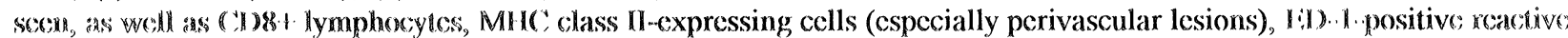

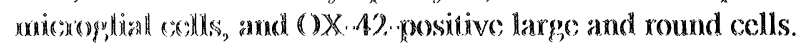



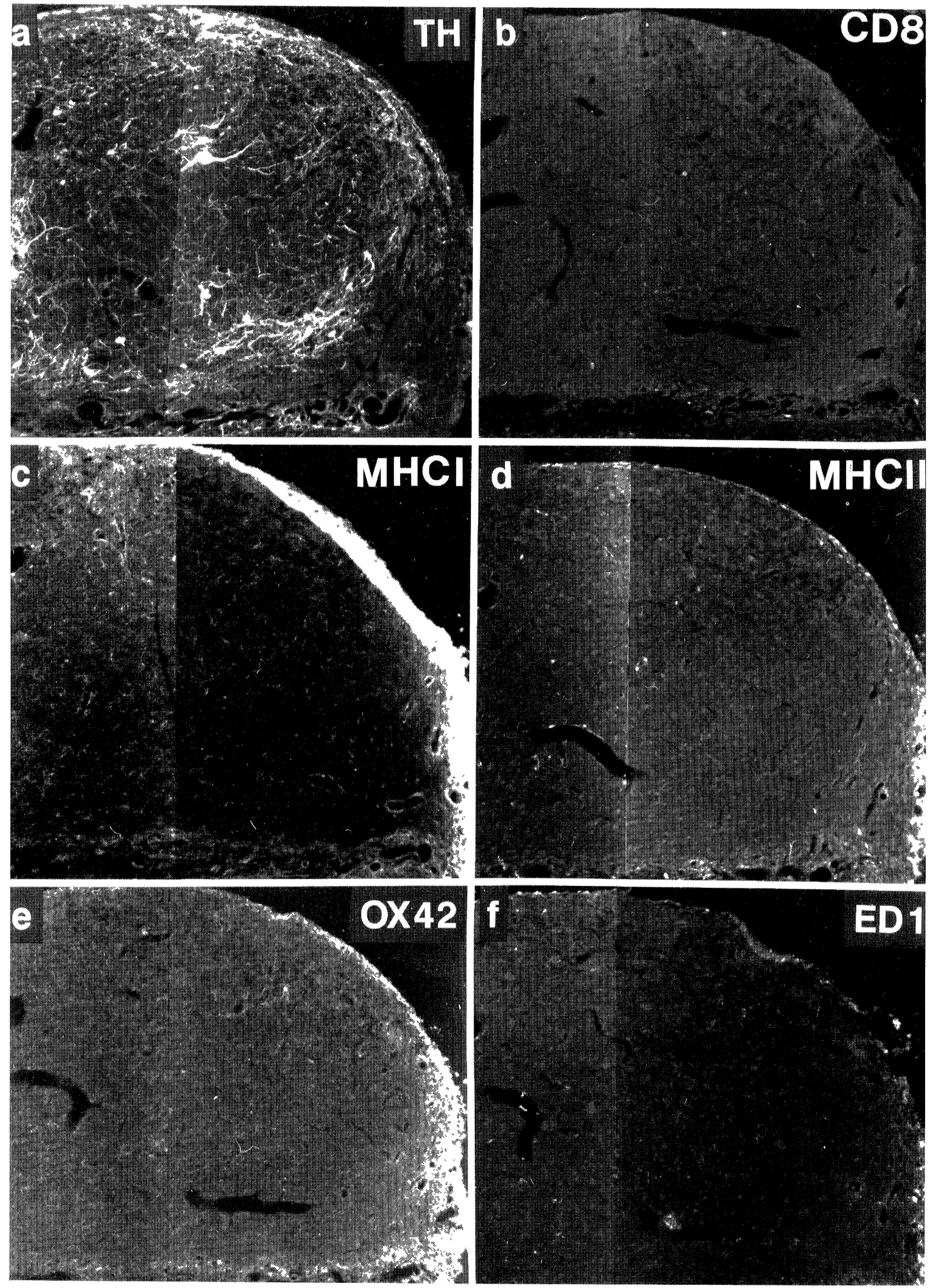

Fig. 7. Typical appearance of transplants after GDNF treatment $(\times 106)$. (a) TH, (b) CD8, (c) MHC I (OX-18), (d) MHC II (OX. 6), (c) (DD11b (OX-42), and (f) ED1-1. Many TH-positive ncurons can be seen in the grafts and quite a few immuncrelated clencnts, except MHC class I-positive microglia. OX-42 labcling shows only ramified microglial cells. 

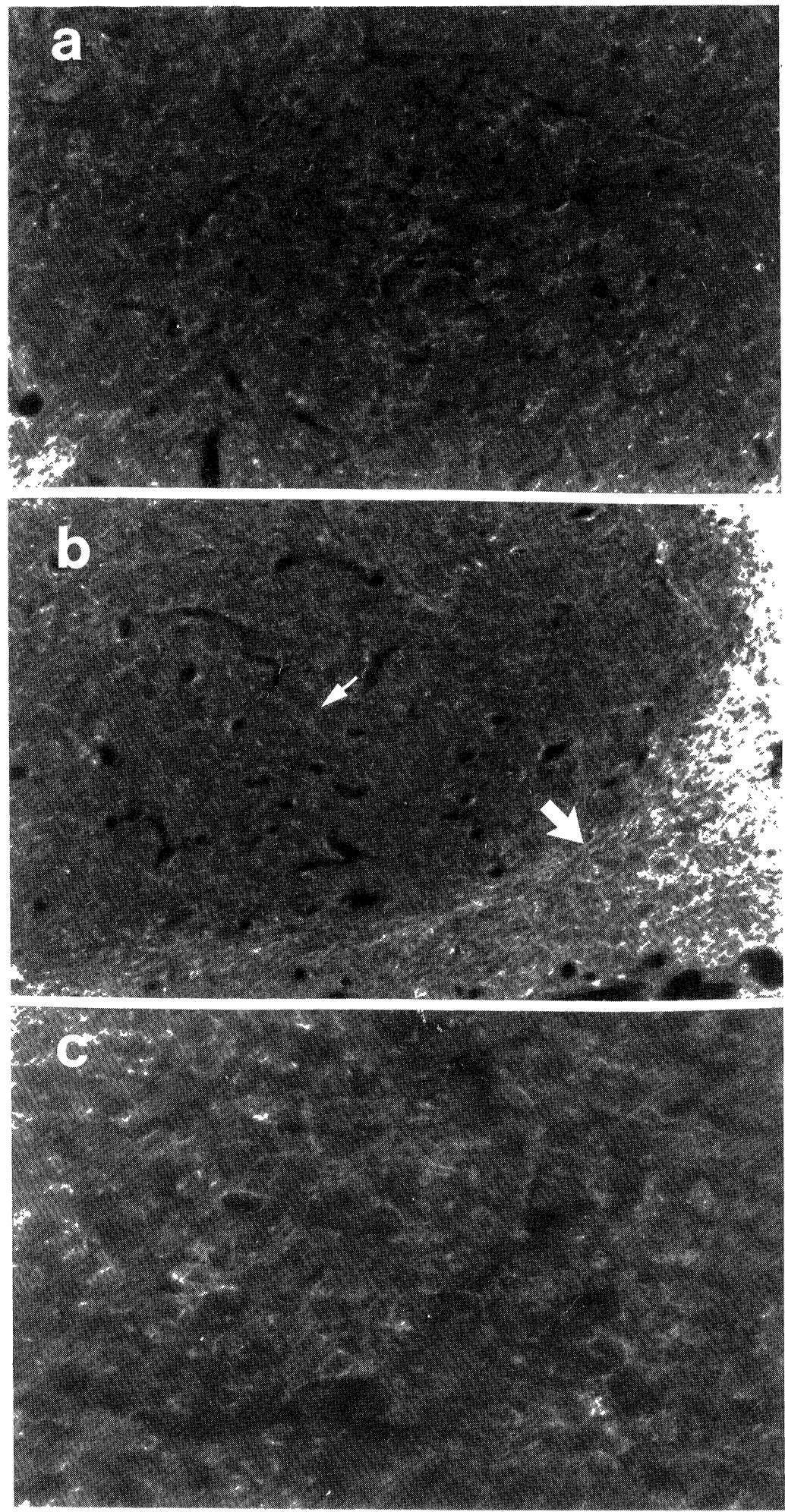

Fig. 8. Morphologic differences seen with OX-42 antibodies. (a) Close-up view of Fig. 5e. GDNF-treated, well-defined ramified microglial cells in the grafts. (b) Close-up view of Fig. 6e. BDNF-treated, partly activated (large and round) microglial elements. (c) Close-up view of Fig. 7e. NT-3-treated severe immunocompromised grafts showing large and round OX-42positive cells in a wide area. 
OX-42-positive ramified microglial cells and a few large, round microglial cells. In addition, GDNFtreated grafts contained a few microglial reactive ED-1-positive microglial cells (Figs. 4b, 4c). Overall, more immunologically com-promised transplants were found in BDNF-treated (3 of 11) and in NT-3-treated groups (5 of 14) than in CCtreated ( 2 of 17$)$ and GDNF-treated groups (3 of 17). Moreover, grafts with a marked infiltration of immune cells were found only in the BDNF- (1) and NT-3-treated (3) groups.

\section{DISCUSSION}

The combined data from this and other studies performed in our laboratories demonstrate that although treatment with GDNF and to some degree with BDNF can enhance immune responses to such immunogenic tissue as fetal spinal cord grafts, the trophic factors per se do not elicit a significant response in non-immunogenic grafts like substantia nigra. In the present study, although GDNF treatment led to significantly larger substantia nigra graft volumes than CC treatment, both GDNF and CC showed almost the same level of immune reactivity, except for MHC class I positive elements. GDNF-treated grafts also had the highest values of normal ramified microglial distribution, as well as lower numbers of immunoreactive microglial components and OX-42 positive round and large microglial cells.

The origin of microglial cells is controversial $/ 20,35 / 42 /$, although most studies have suggested a mesodermal origin $77,25,27,33 /$. Three types of microglial cells are found in the CNS. Ramified microglia, prominent in the mature CNS, are derived from ameboid microglia, which, in turn, are present during late prenatal and early post-natal ages. Reactive microglia appear primarily in cases of CNS injury (reviewed in $/ 19,27,33,45 /$ ). After 6-OHDA-induced dopaminergic denervation, microglial cells in substantia nigra have been shown to express MHC loci /1/, and ED1 and OX-42positive microglial cells have also been found in the substantia nigra area (Shinoda, Lindqvist, and Olson, unpublished).

As mentioned before, GDNF belongs to the TGF- $\beta$ superfamily $/ 24 /$ of immunomodulators.
TGF- $\beta$ is produced by a large number of different cell types, including various cells of the immune system, such as macrophages, peritoneal monocytes and neutrophils, as well as by $T$ - and Blymphocytes. In cases of injury (localized inflammation), platelet aggregation and degranulation, one of the earliest events in the inflammatory response, might occur and trigger the release of TGF $\beta$. Activated macrophages release TGF- $\beta$ and other cytokines (for example, interleukin-1 (IL-1), tumor necrosis factor (TNF), fibroblast growth factor (FGF), and platelet-derived growth factor (PDGF). The inhibition of T-cell proliferation by TGF- $\beta$ may reduce the inflammatory response while promoting healing $151 /$. Interestingly, TGF- $\beta 1$ null/deficient mice show increased MHC Classes I and II gene expression $/ 12 /$, as well as an increased inflammatory-cell infiltration of cardiac tissue that is related to allogeneic cardiac tissue rejection /53/.

We previously reported that in the SpragueDawley strain of rats, GDNF-treated intraocular allogeneic spinal cord grafts showed the highest cytotoxic immune responses when compared with BDNF- and CC-treated grafts. In contrast, we saw no immune upregulation after GDNF treatment in syngeneic Fisher strain spinal cord grafts /40/. Comparing fetal spinal cord grafts $/ 40 /$ with the embryonic substantial nigra grafts to the eye chamber reported here reveals that the immune reactions elicited by spinal cord tissue tends to be more pronounced than those induced by ventral mesencephalic tissue. Two major reasons could account for the neuroimmunologic differences between cerebral gray matter and the spinal cord in development. First, normal mature spinal cord contains MHC Class I positive microglial cells $/ 22 /$. Additionally, in $\mathrm{P} 1$ rats $\mathrm{MHC}$ Class I-positive microglial cells can be found on the surface of cervical and thoracic spinal cord, and they increase in number and appear to move into the white matter with time so that several weeks after birth, they become normal MHC Class I-positive microglial cells (Shinoda, Kobayashi, and Olson, unpublished). Substantia nigra, however, does not contain MHC Class I-positive microglia (Shinoda, Kobayashi, and Olson, unpublished). Second, the spinal cord also contains a large proportion of white matter, which contains more ameboid microglial cells during 
development $/ 16 /$. Because they can express MHC loci and Il-1 /13,26/, ameboid and/or activated microglial cells may contain more immunomodulatory components.

Stromberg et al. $144 /$ reported using the same procedures, in which $0.1,1 \mu \mathrm{g}$, and $1 \mathrm{mg} /$ eye GDNF were given to stimulate neuronal growth. In the present study, the final sizes of GDNF-treated substantia nigra transplants were more than 1.5 -fold larger than those in Stromberg's experiments. The reasons for such differences are as follows: (a) We used 8 injections of GDNF at 5-day intervals, and the final period was 42 days after the first injection, whereas in the former experiments the final period was only 33 days.

Nerve growth factor (NGF) and other neurotrophins have been shown to produce several immunomodulatory effects, such as in mast cells $12,3,32 /$, B-cell stimulation $/ 31,43,46 /$ and T-lymphocyte stimulation $/ 47 /$. In the present study, NT-3, which had no effect on graft growth, elicited small immunomodulatory effects, particularly microglial activation. The significantly increased numbers of OX-42-positive large and round cells in NT-3-treated transplants suggests that NT-3 stimulates macrophage-related cytotoxic immunity in neuronal cells. NT-3 and NT-4 mRNA, as well as truncated trkB and trkC transcripts, have been found in rat thymus, thymic stroma (tissue depleted of mononuclear cells), spleen, and splenic stroma 123/. Concanavalin A-treated rat-thymus cells and lipopolysaccharide-treated rat-spleen mononuclear cells express a two-fold increase in NT-4 but not in NT-3 or BDNF. We have previously shown that BDNF has almost no immunomodulatory effect on fetal spinal cord grafts in oculo /40/. Thus it appears that BDNF does not elicit a strong immunoreaction in vivo.

In conclusion, neither GDNF nor BDNF enhanced immune reactivity in allogeneic embryonic substantia nigra grafts. GDNF may act to upregulate immune markers in allogeneic CNS tissue grafts where MHC Class $I$ is strongly expressed, such as in spinal cord, but not in allogeneic CNS tissue in which MHC Class I is weakly expressed, such as in substantia nigra.

\section{ACKNOWLEDGMENTS}

This project was supported by the Swedish MRC and the United States Public Health Service. The authors thank Susanne Almstrom, Monica Casserlov, and Karin Lundstromer for expert technical assistance, and Ida Engqvist for editorial support. The authors are also grateful to Ingrid Stromberg for her technical assistance, comments, and overview of this manuscript. GDNF was a generous gift from Amgen Inc.

\section{REFERENCES}

1. Akiyama H, McGeer PL. Microglial response to 6-hydroxydopamine-induced substantia nigra lesions. Brain Res 1989; 489: 247-253.

2. Aloe L. The effect of nerve growth factor and its antibody on mast cells in vivo. J Immunol 1988; 18: 1-12.

3. Aloe LR, Levi-Montalcini R. Mast cell increase in tissues of neonatal rats injected with nerve growth factor. Brain Res 1977; 133: 358-366.

4. Beck KD, Valverde J, Alexl T, Poulsen K, Moffat B, Vandlen RA, et al. Mesencephalic dopaminergic neurons protected by GDNF from axotomy-induced degeneration in the adult brain. Nature 1995; 373: 339-341.

5. Bjorklund H, Olson L, Seiger A, Hoffer B. Chronic lead and brain development: Intraocular brain grafts a a method to reveal regional and temporal effects in the cerebral nervous system. Environ Res 1980; 224-236.

6. Cheng H, Hoffer B, Stromberg I, Russell D, Olson L. The effect of glial cell line-derived neurotrophic factor in fibrin glue on developing dopamine neurons. Exp Brain Res 1995; 104: 199-206.

7. Chugani DC, Kedersha NL, Rome LH. Vault immunofluorescence in the brain: New insights regarding the origin of microglia. J Neurosci 1991; 11: 256-268.

8. Dijkstra CD, Dopp EA, Joling P, Kraal G. The heterogeneity of mononuclear phagocytes in lymphoid organs: Distinct macrophage subpopulations in the rat recognized by monoclonal antibodies ED-1, ED-2, and ED-3. Immunology 1985; 54: 589-599.

9. Ellison JA, DeVellis J. Ameboid microglia expressing GD3 ganglioside are concentrated in regions of oligodendrogenesis during development of the rat corpus callosum. Glia 1995; 14: 123-132.

10. Fontana A, Constam DB, Frei K, Malipiero U, Pfister HW. Modulation of the immune response by transforming growth factor $\beta$. Int Arch Allergy Immunol 1992; 99, 1-7. 
11. Gash DM, Zhang Z, Ovadia A, Cass WA, Simmerman $\mathrm{L}$, Russel D, et al. Functional recovery in Parkinsonian monkeys treated with GDNF. Nature 1996; 380: 252.

12. Geiser AG, Letterio JJ, Kulkarno Ab, Karlsson S, Roberts AB, Sporn MB. TGF- $\beta 1$ controls expression of major histocompatibility genes in the postnatal mouse: Aberrant histocompatibility antigen expression in the pathogenesis of the TGF- $\beta 1$ null mouse phenotype. Proc Natl Acad Sci USA 1993; 90: 9944-9948.

13. Giulian D, Baker TJ, Shih LC, Lachman LB. Interleukin 1 of the central nervous system is produced by ameboid microglia. J Exp Med 1986; 164: 594-604.

14. Graeber MB, Streit WJ, Kreutzberg GW. Axotomy of the rat facial nerve leads to increased CR3 complement receptor expression by activated microglial cells. J Neurosci Res 1988; 21: 18-24.

15. Hooper WC. The role of transforming growth factor- $\beta$ in hematopoiesis. A review. Leuk Res 1991; 15: 179.

16. Hutchins KD, Dickson DW, Rashbaum WK, Lyman WD. Localization of microglia in the human fetal cervical spinal cord. Dev Brain Res 1992; 66: 270-273.

17. Hyman C, Hofer M, Barde YA, Juhasz M, Yancopoulos GD, Lindsay RM. BDNF is a neurotrophic factor for dopaminergic neurons of the substantia nigra. Nature 1991; 350: 230-232.

18. Johansson M, Friedemann M, Hoffer B, Stromberg I. Effects of glial cell line-derived neurotrophic factor on developing and mature ventral mesencephalic grafts in oculo. Exp Neurol 1995; 134: 25-34.

19. Jordan FL, Thomas WE. Brain macrophages: Question of origin and interrelationship. Brain Res Rev 1988; 13: $165-178$.

20. Kitamura T, Miyake T, Fujita S. Genesis of resting microglia in the gray matter of mouse hippocampus. J Comp Neurol 1984; 226: 421-433.

21. Knusel B, Winslow JW, Rosenthal A, Burton LE, Seid DP, Nikolics K, Hefti F. Promotion of central cholinergic and dopaminergic neuron differentiation by brain-derived neurotrophic factor but not neurotrophin 3. Proc Natl Acad Sci USA 1991; 88: 961-965.

22. Koshinaga M, Whittemore SR. The temporal and spatial activation of microglia in fiber tracts undergoing antegrade and retrograde degeneration following spinal cord lesion. J Neurotrauma 1995; 12: 209-222.

23. Laurenzi MA, Barbany G, Timmusk T, Lindgren JA, Persson $H$. Expression of mRNA encoding neurotrophins and neurotrophin receptors in rat thymus, spleen tissue, and immunocompetent cells. Regulation of neurotrophin-4 mRNA expression by mitogens and leukotriene B4. Eur J Biochem 1994; 223: 733-741.

24. Lin LF, Doherty DH, Lile JD, Bektesh S, Collins F. GDNF: A glial cell line-derived neurotrophic factor for midbrain dopaminergic neurons. Science 1993; 260: 1130-1132.

25. Ling EA. Transformation of monocytes into amoeboid microglia in the corpus callosum of postnatal rats, as shown by labeling monocytes by carbon particles. J Anat 1979; 128: 847-858.

26. Ling EA, Kaur C, Wong WC. Expression of major histocompatibility complex and leukocyte common antigens in amoeboid microglia in postnatal rats. $\mathrm{J}$ Anat 1991; 177: 117-126.

27. Ling EA, Wong WC. The origin and nature of ramified and amoeboid microglia: A historical review and current concepts. Glia 1993: 7: 9-18.

28. McCartney-Francis NL, Wahl SM. Transforming growth factor- $\beta$ : A matter of life and death. J Leukocyte Biol 1994; 55: 401-409.

29. Olson L, Seiger A, Stromberg I. Intraocular transplantation in rodents. A detailed account of the procedure and examples of its use in neurobiology with special reference to brain tissue grafting. In S. Federoff, ed., Advances in Cellular Neurobiology, Vol. 4, Orlando: Academic Press, 1983; pp. 407-442.

30. Oppenheim RW, Houenou LJ, Johnson JE, Lin L-FH, $\mathrm{Li} \mathrm{L}$, Lo AC, et al. Developing motor neurons rescued from programmed and axotomy-induced cell death by GDNF. Nature 1995; 373: 344-346.

31. Otten U, Ehrhard P, Peck R. Nerve growth factor induces growth and differentiation of human B lymphocytes. Proc Natl Acad Sci USA 1989; 86: 10059-63.

32. Pearce FL, Thompson HL. Some characteristics of histamine secretion from rat peritoneal mast cells stimulated with nerve growth factor. J Physiol 1986; 372: 379-393.

33. Perry VH, Hume DA, Gordon S. Immunohistochemical localization of macrophages and microglia in the adult and developing mouse brain. Neuroscience 1985; 15: 313-326.

34. Price ML, Hoffer BJ, Granholm A-C. Effects of GDNF on fetal septal forebrain transplants in oculo. Exp Neurol 1996; 141: 181-189.

35. Rio-Hortega P. Microglia. In: Penfield W, ed., Cytology and cellular pathology of the nervous system. Paul B. Hoeber Inc, 1932; pp. 481-584.

36. Robinson AP, White TM, Mason DW. Macrophage heterogeneity in the rat as delineated by two monoclonal antibodies MRC Ox-41 and MRC Ox-42, the latter recognizing complement receptor type 3 . Immunology 1986; 57: 239-347.

37. Sauer H, Rosenblad C, Bjorklund A. Glial cell linederived neurotrophic factor but not transforming growth factor $\beta 3$ prevents delayed degeneration of nigral dopaminergic neurons following striatal 6-hydroxydopamine lesion. Proc Natl Acad Sci USA 1996; 92: 8935-8939.

38. Schmidt-Kastner R, Tomac A, Hoffer BJ, Bektesh S, Rosenzweig B, Olson L. Glial cell line-derived neurotrophic factor (GDNF) mRNA upregulation in striatum and cortical areas after pilocarpine-induced status epilepticus in rats. Molec Brain Res 1994; 26: 325-330.

39. Shinoda M, Giacobini MJ, Kastner-Shmidtner R, Trok 
K, Olson L. Differential immune responses to fetal intracameral spinal cord and cortex cerebri grafts. Exp Brain Res 1996; 110: 223-234.

40. Shinoda M, Hoffer BJ, Olson L. Interactions of neurotrophic factors GDNF and NT-3, but not BDNF with the immune system following fetal spinal cord transplantation. Brain Res 1996; 722: 153-167.

41. Shinoda M, Hudson J, Stromberg I, Hoffer BJ, Moorhead JW, Olson L. Allogeneic grafts of fetal dopamine neurons: Immunological reactions following active and adoptive immunizations. Brain Res 1995; 680: 180-195.

42. Sminia T, DeGroot CJA, Dijkstra CD, Koetsier JC, Polman CH. Macrophages in the central nervous system of the rat. Immunobiology 1987; 174: 43-50.

43. Stepien H, Lyson K, Stanisz AM, Pawlikowski M. The effect of nerve growth factor on DNA synthesis, cyclic AMP and cyclic GMP accumulation by mouse spleen lymphocytes. Int J Immunopharmac 1991; 13: 51-56.

44. Stromberg I, Bjorklund A, Johansson M, Tomac A, Collins F, Olson L, et al. Glial cell line-derived neurotrophic factor is expressed in the developing but not adult striatum and stimulates developing dopamine neurons in vivo. Exp Neurol 1993; 124: 401-12.

45. Thomas WE. Brain macrophages: Evaluation of microglia and their functions. Brain Res Rev 1992; 17: 61-74.

46. Thorpe LW, Perez-Polo JR. The influence of nerve growth factor on the in vitro proliferative response of rat spleen lymphocytes. J Neurosci Res 1987; 18: 134.
47. Thorpe LW, Warrbach-Perez K, Perez-Polo JR. Effect of nerve growth factor on expression of interleukin-2 receptors on cultured human lymphocytes. Ann NY Acad Sci 1987; 496: 310-313.

48. Tomac A, Lindqvist E, Lin L-FH, Ogren SO, Young $\mathrm{D}$, Hoffer BJ, Olson L. Protection and repair of the nigrostriatal dopaminergic system by GDNF in vivo. Nature 1995; 373: 335-339.

49. Trok K, Hoffer BJ, Olson L. Glial cell line-derived neurotrophic factor enhaces survival and growth of pre- and postnatal spinal cord transplants. Neuroscience 1995; 71: 231-241.

50. Wahl SM, Costa GL, Mizel DE, Allen JB, Skaleric U, Mangan DF. Role of transforming growth factor $\beta$ in the pathophysiology of chronic inflammation. J Periodont 1993; 64: 450-455.

51. Wahl SM, McCartney-Francis N, Meergenhagen SE. Inflammatory and immunomodulatory roles of TGF- $\beta$. Immunology Today 1989; 10: 258-261.

52. Waltenberger J, Miyazono K, Funa K, Wanders A, Fellstrom B, Heldin CH. Transforming growth factor- $\beta$ and organ transplantation. Transplant Proc 1993; 25: 2038-2040.

53. Waltenberger J, Wanders A, Fellstrom B, Miyazono $\mathrm{K}$, Heldin $\mathrm{CH}$, Funa $\mathrm{K}$. Induction of Transforming growth factor- $\beta$ during cardiac allograft rejection. J Immunol 1993; 151: 1147-1157.

54. Yan $\mathrm{Q}$, Matheson C, Lopez OT. In vivo neurotrophic effects of GDNF on neonatal and adult facial motor neurons. Nature 1995; 373: 341-344. 

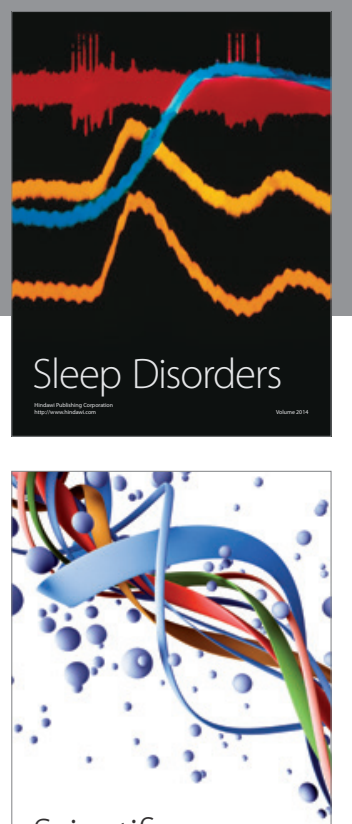

Scientifica
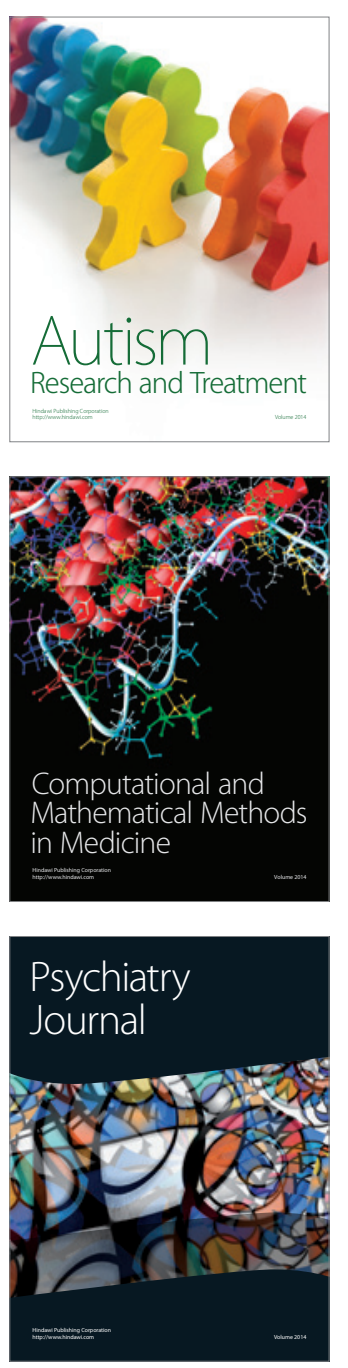
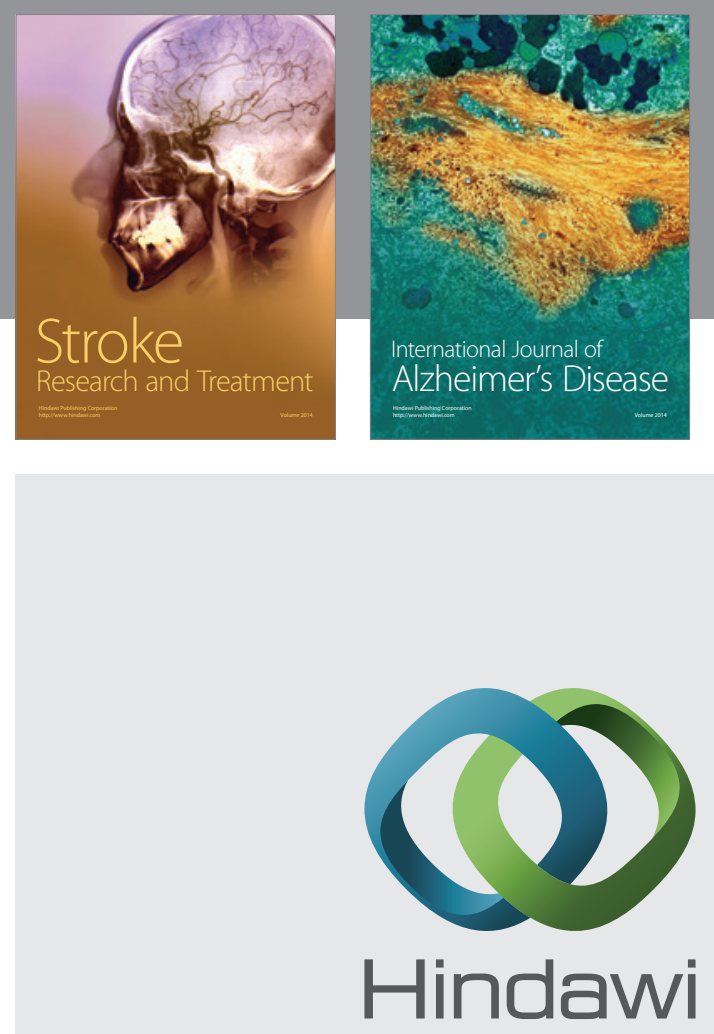

Submit your manuscripts at

http://www.hindawi.com
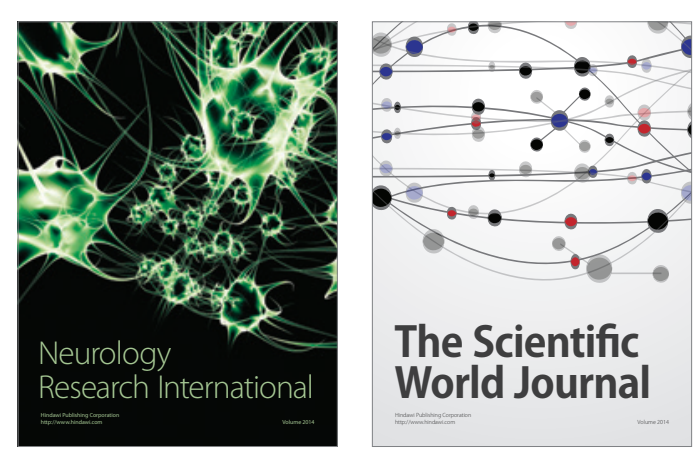

The Scientific World Journal

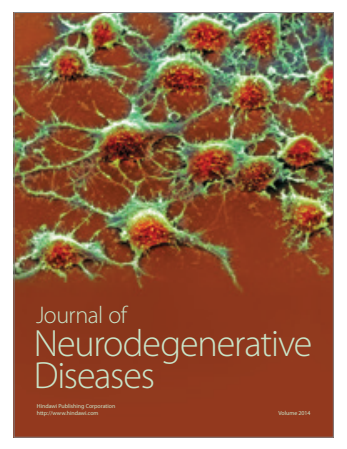

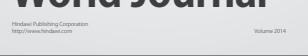

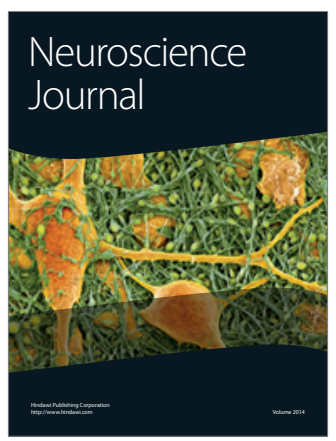

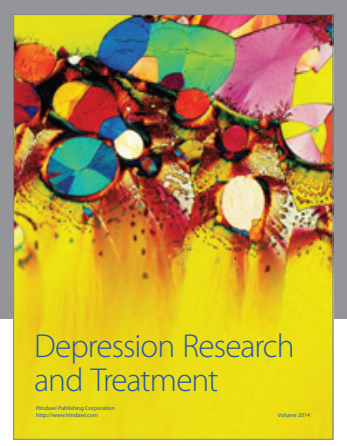
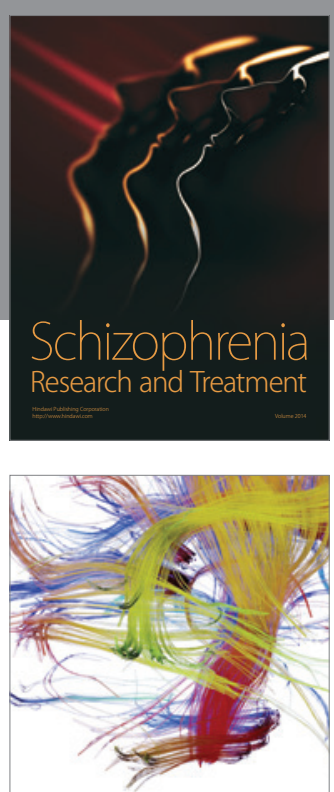

Brain Science

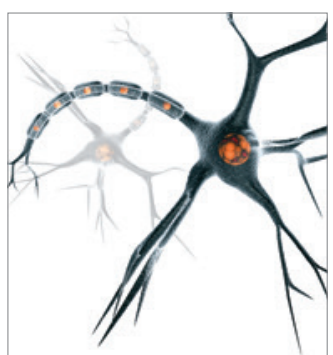

Neural Plasticity
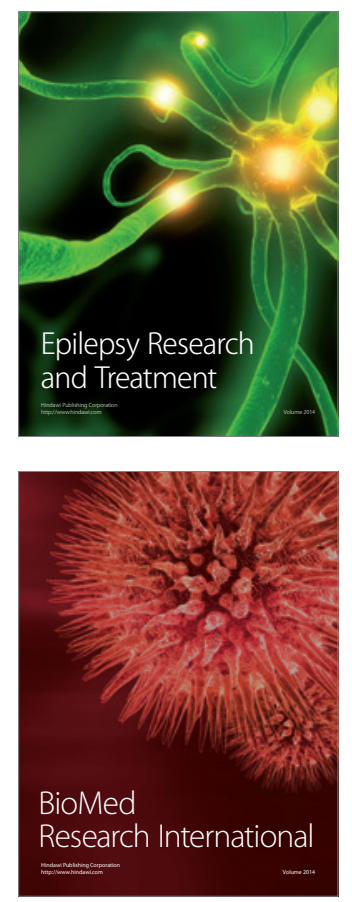

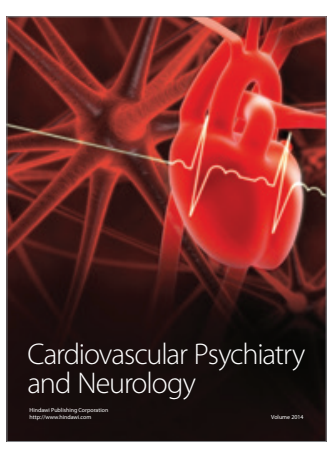

Parkinson's

Disease
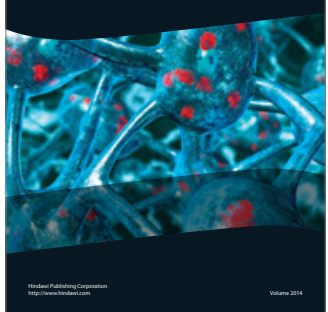